Document downloaded from:

http://hdl.handle.net/10251/35982

This paper must be cited as:

Reyes Tolosa, MD.; Orozco Messana, J.; Hernández Fenollosa, MDLA.; Bolink, HJ.; Camaratta, R.; Niedersberg Correia, Á.; Soriano, A.... (2011). Low cost hybrid solar cell integration on wall tiles. ECS Transactions. 41(4):141-146.

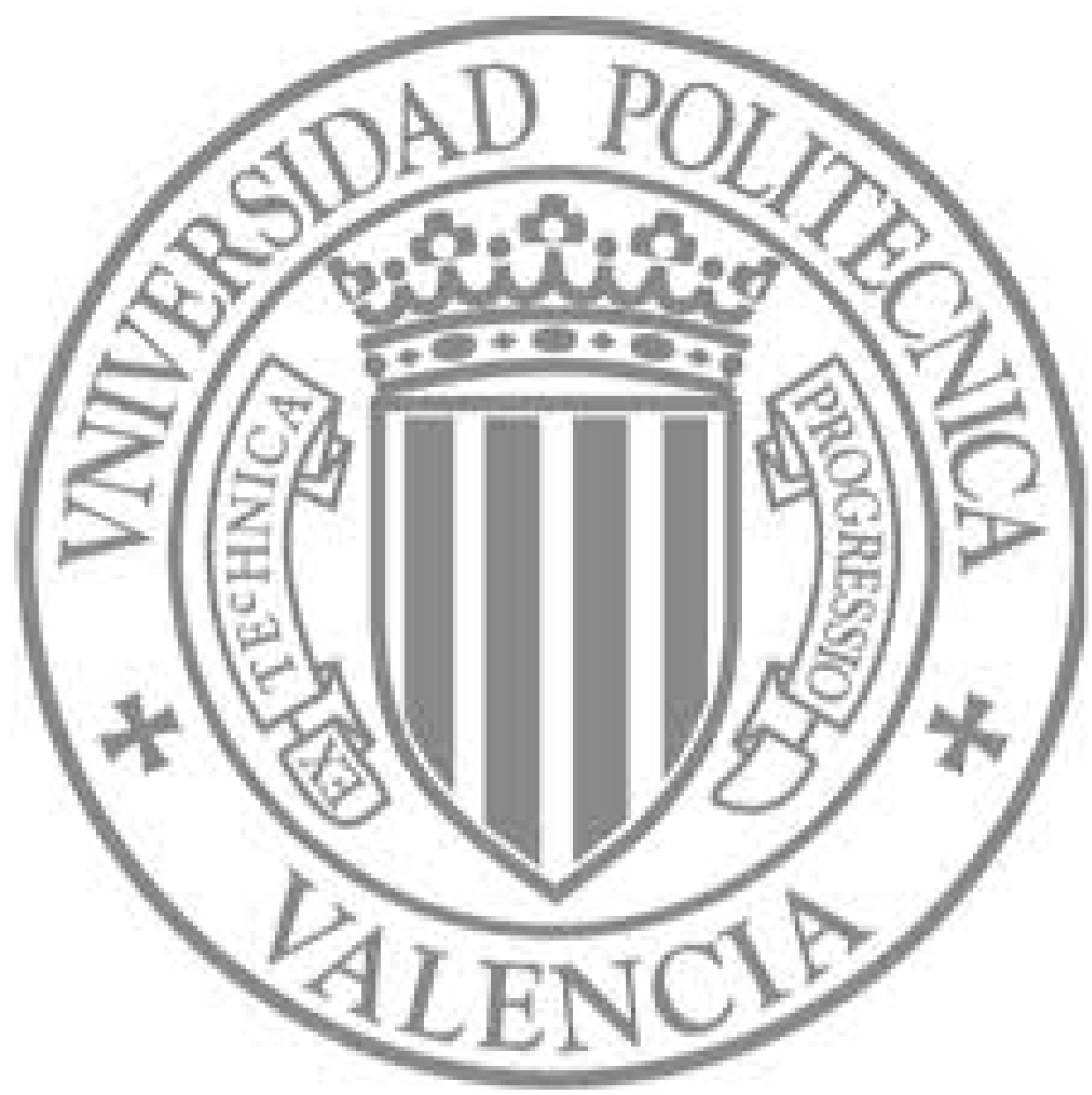

The final publication is available at

http://ecst.ecsdl.org/content/41/4/141

Copyright Electrochemical Society 


\title{
Low cost hybrid solar cell integration on wall tiles
}

\author{
M.D.Reyes*(1), J.Orozco(1), M.A. Hernández-Fenollosa(1), R.Camaratta (1), \\ A.Niedersberg (1), H.J. Bolink(2), A.Soriano(2), H.Brine (2) \\ (1) Universidad Politecnica Valencia, ITM Camino Vera s/n, 46022 (Valencia, Spain) \\ (2) Instituto de Ciencia Molecular, Universidad de Valencia \\ *mareto@upvnet.upv.es
}

\begin{abstract}
On this paper the first Building Integrated Hybrid Photovoltaic (BIHPV) cell obtained on a commercial tile is presented. The experimental techniques used allow a future low cost development of these cells for its massive use on facades for buildings. The basic concept includes a metal projected layer as back contact with an electron injection layer of electrodeposited $\mathrm{ZnO}$, an organic PBCBM/P3HT photovoltaic cell with a closing TCO thin film on top. Integration with the substrate problems have been solved and allow further work on cell performance and durability.
\end{abstract}

\section{Introduction}

In recent years, the search to develop large-area solar cells at low cost has led to research on photovoltaic (PV) systems based on nanostructures embedded with polymer based mixtures (1). Reduction in the production costs and improved solar cell performance are the main factors driving current research and development efforts in the solar cell field. The performance issue centers around increased solar cell efficiency while the cost factor is on the use of a variety of substrates and deposition techniques to control production costs. With recent increase in building integrated photovoltaics (BIPV) (2), a concept where installed photovoltaics modules provide both energy selfsufficiency for the house as well as other functions such as thermal insulation and shade, innovative choice of substrate material is called for. Commercial ceramics can fulfill the concept of a "combined power generator and building element envelop" if the ceramic tiles on walls and structures are used to substitute for the PV module tiles. The substitution eliminates further module assembly costs (3).

The structure for the cell is based on a zinc conductive layer thermal projected on to a glazed commercial tile. Later a $\mathrm{ZnO}$ nanostructured film is electrochemically grown for later spin coating of a PCBM-P3HT blend.

The first step was to create an even surface through a low melting point glaze researched on previous work. The surface is thermally projected by zinc poder to create the conductive contact.

The electrodeposition is studied in detail in order to attain the desired morphology control and surface characteristics. Although thin, the process develops a primary oxide layer playing an important role on the properties of the nanostructured films grown on top of them (4). Additionally, these primary oxide layers prevent direct hole combination in hybrid organic-inorganic solid state solar cells. We show that the 
properties of the $\mathrm{ZnO}$ nanostructured films depend strongly on the primary oxide covered substrate (5).

Additionally, we will present the effect of the primary layers on the performance of hybrid solar cells based on the three types of $\mathrm{ZnO}$ nanostructured films and the organic p-type semiconductor regio-regular poly(3-hexylthiophene) (P3HT) (6). The photovoltaic cells obtained by these methods have been characterized by scanning electron microscopy and I-V measurements under a solar simulator, showing the viability of these low cost devices.

\section{Sample preparation}

Ceramic substrates

A commercial ceramic product was used with a porcelain microstructure. This is a typical porcelain tile, which was characterized with regard to its chemical composition and dilatometry. In the chemical composition, those atomic species that are dangerous for photovoltaic material were looked for. As shown in the X-ray diffractogram (figure 1 ), only the presence of sodium was detected. In the dilatometry, the optimum firing temperature $\left(1200^{\circ} \mathrm{C}\right)$ was determined for adjusting the formulation of the glaze that was applied on to the pressed porcelain tile before firing.

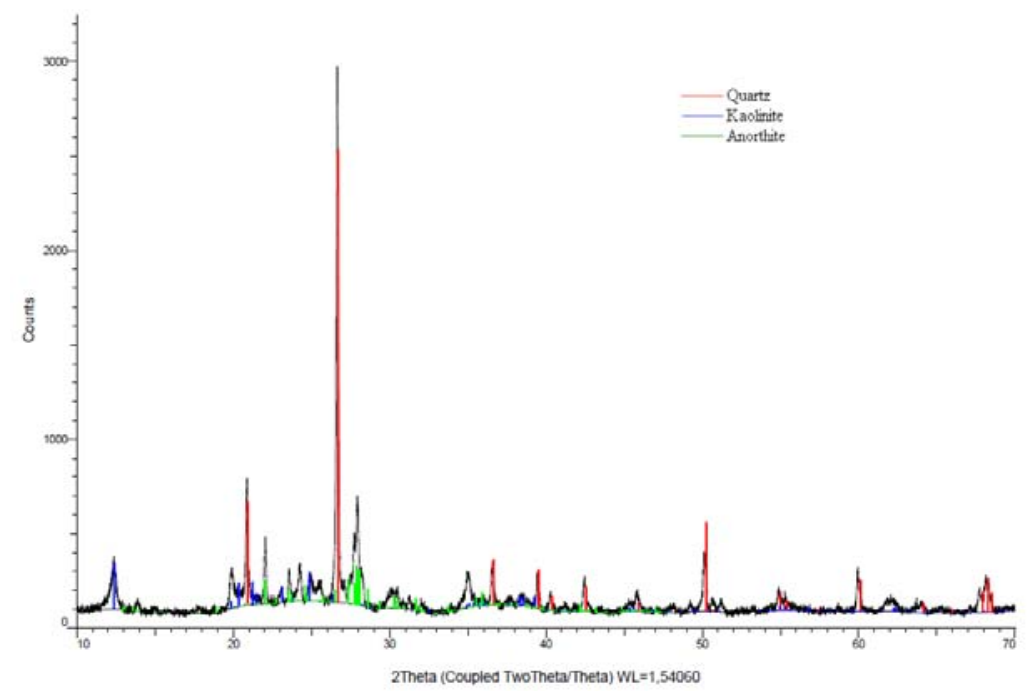

Figure 1. X-Ray Diffractogram of the raw material for pressing.

The glaze was formulated based on 200-gram batches of suspension. The design objective was focused on obtaining a fluxing glaze with no sodium content and with sufficient percentages of zinc (in the form of $\mathrm{ZnO}$ ) and titanium dioxide (in the form of anatase) to effectively act as a barrier layer. At the same time, a sintering temperature of over $900^{\circ} \mathrm{C}$ has to be reached, with softening at over $1100^{\circ} \mathrm{C}$ and fusion in the range of $1270-1300^{\circ} \mathrm{C}$ for compatibility with the body. In all the formulations, the following quantities of components for 200 grams of suspension are repeated:

- 120 g powdered glaze.

- $\quad 1.6 \mathrm{~g}$ dispersant (fish oil).

- $64 \mathrm{~g}$ solvent (ethanol with acetone at $50 \mathrm{vol} \%$ ).

- $\quad 10.4 \mathrm{~g}$ binding agent (polyvinyl butyral or PVB).

- 4 g plasticizer (benzyl butyl phthalate or BBP). 
The glaze powder consisted of $\mathrm{ZnO}$ powder ( $99 \%$ purity), anatase ( $99 \%$ purity), quartz, metallic zinc powder, feldspar and alumina. The suspension was ground in a ball mill for one hour for homogenization observing the suppliers' particle sizes. The glaze was then applied on to the pressed substrate using the tape-casting technique with a green thickness of $2 \mathrm{~mm}$. The final mixture was fired in an industrial oven at $1200^{\circ} \mathrm{C}$.

\section{Thermal Spraying and polishing,}

The fired ceramic samples were subjected to thermal spraying of microstructured zinc powder (Castodyn 30-40 $\mu \mathrm{m}$ ) using a Castodyn DS 10 oxyacetylene spray gun (7) in order to obtain suitable bonding between the layer to be electrodeposited and the ceramic glaze (8). The samples obtained this way were also subjected to polishing in order to determine the importance of surface polishing on the corrosion performance of the $\mathrm{Zn}$ layer and the electric performance of these samples after electrodeposition of $\mathrm{ZnO}$. Polishing was done manually using $1 \mu \mathrm{m}$ diamond, and automatically (using vibration in a Bruehler Vibromet apparatus) for 3, 6, 9 and 12 hours with $0.25 \mu \mathrm{m}$ diamond. This was intended to determine the influence of polishing on the performance of these layers. The times and particle sizes selected matched the most representative data in the literature (9). The microstructure obtained is shown on figure 2 .

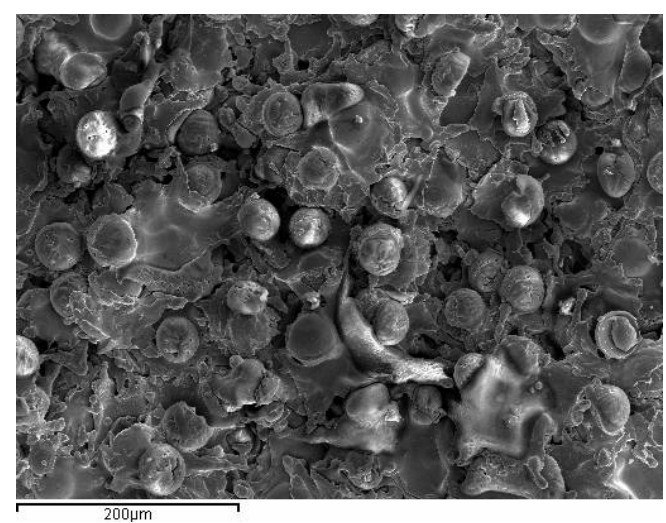

a) metallic surface after $\mathrm{Zn}$ projection

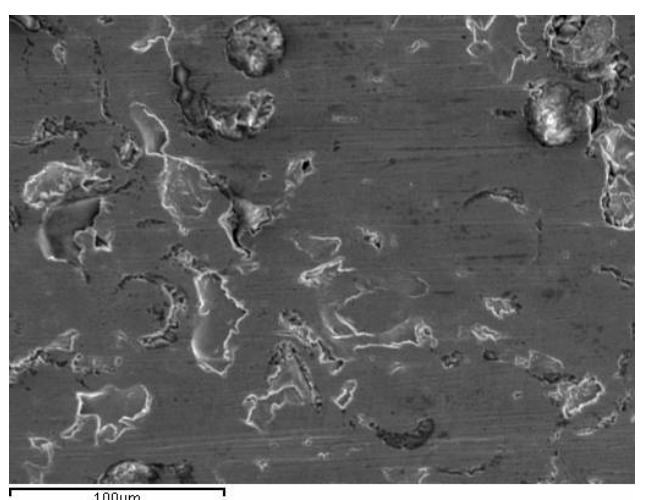

b) metallic surface after $12 \mathrm{hrs}$ polish
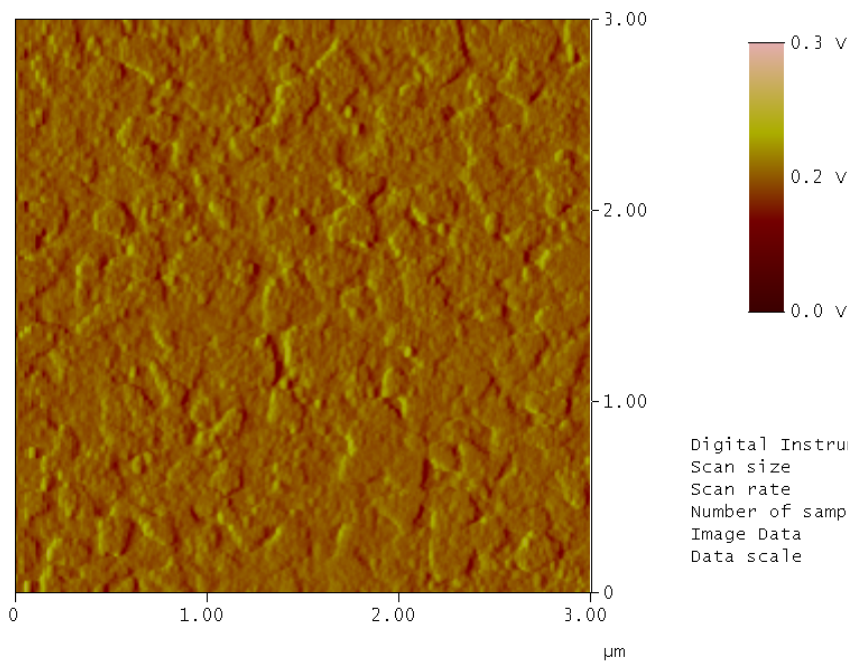

c) AFM surface map after $12 \mathrm{hrs}$ polish

Figure 2. Morphology characterisation of the $\mathrm{Zn}$ thermal sprayed porcelain tile. 


\section{Electrodeposition.}

The samples with the conductive layer were degreased with ultrasounds in a mixture of acetone and ethanol for 5 minutes, to then be rinsed in distilled water and dried with blown air just before being coated. The samples were then electrolytically coated through pulsed current electrodeposition (10) with an electrolyte with a composition of $0.005 \mathrm{M} \mathrm{ZnCl}_{2}$ and $0.1 \mathrm{M} \mathrm{KCl}$. A thermostatted bath was used for the cell at an optimum temperature of $75^{\circ} \mathrm{C}$. The cell assured the working conditions and bubbling oxygen for a platinum counter-electrode and a reference electrode of $\mathrm{Ag} / \mathrm{AgCl}$. These working conditions allow homogeneous layers of $\mathrm{ZnO}$ to be obtained with the proper morphological characteristics for them to be used as an inorganic electron injection layer for low-cost hybrid cells to be developed some time in the future on this basis. On figure 3 the electrodeposition curve is presented.

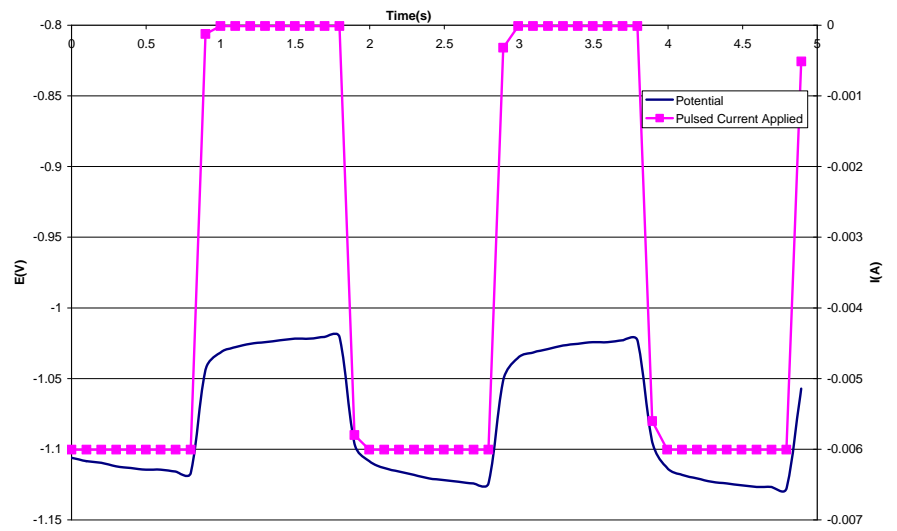

Figure 3. Pulsed current electodeposition of $\mathrm{ZnCl}_{2} 5 \cdot 10^{-3} \mathrm{M}$ and $\mathrm{KCl} 0.1 \mathrm{M}$ solution, at $70^{\circ} \mathrm{C}$.

$\underline{\text { Spin P3HT-PCBM and Evaporation of } \mathrm{MoO}_{3}} \underline{\text { and } \mathrm{Au}}$.

The P3HT:PCBM (1:0.8, w/w) solutions were prepared in pure good solvent (Dichlorobenzene) and stirred for $48 \mathrm{~h}$ under $\mathrm{N}_{2}$ conditions. Photovoltaic cells were fabricated under ambient conditions according to the standard device fabrication procedure (11).

The photoactive layer was fabricated by depositing the prepared solution via spin coating $(20 \mathrm{~s}, 500 \mathrm{rpm})$. The resulting thickness of the photoactive layer was around $200 \mathrm{~nm}$. Finally, the devices were completed by the evaporation of a $\mathrm{MoO}_{3}$ transparent front electrode at a pressure lower than $10^{-6}$ mbar. An additional gold evaporated contact was required for measurements.

\section{Experimental}

The samples were characterised at all stages prior to the photoactive blend deposition in order to ensure the correct cell morphology. The characterisation included SEM and AFM the main issue was to ensure a completely flat $(<12 \mathrm{~nm} \mathrm{Rz})$ and "pinhole" free surface. For the electrodeposition it was also important to ensure a compact layer (10).

At the last stage the photoactive blend was spin coated as described before and the transparent front contact closed the cell structure presented on figure 4 . 


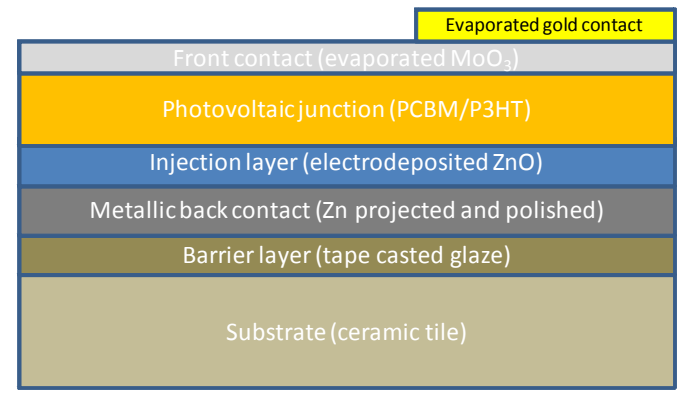

Figure 4. BIHPV cell structure.

After completing the cell it was tested for quantum efficiency on a lab test bench capable of measuring the I-V response under different lighting conditions. The light source used was a Hamamatsu L2175 Xenon lamp. On figure 5 the current response of the cell is shown for different lighting (voltage on the lamp) conditions. The cell response is better than expected at lower lamp voltages due to the photoactive response.

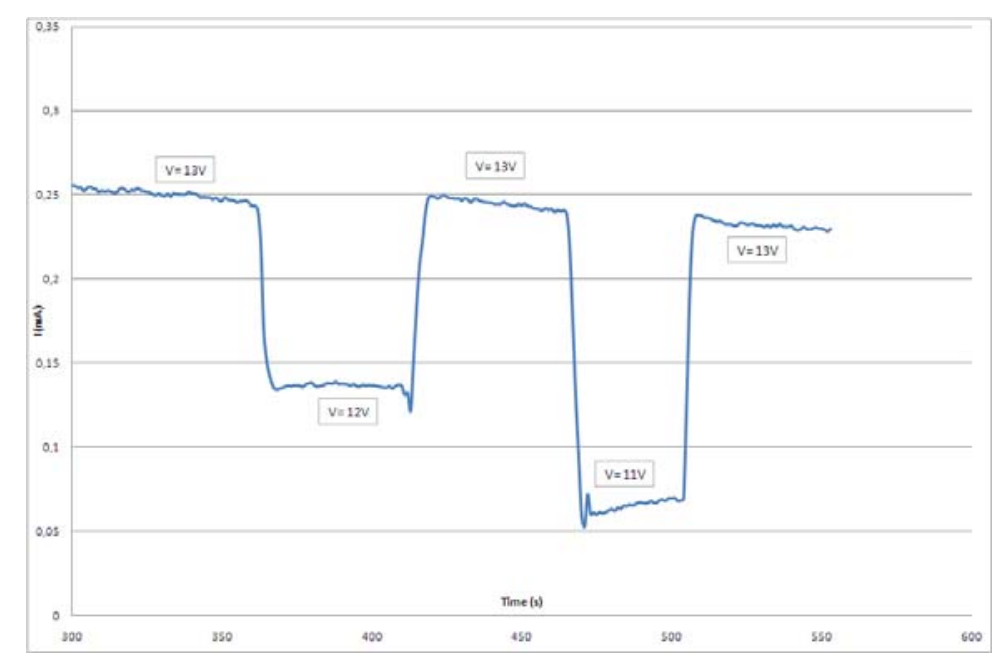

Figure 5. Current response for the BIHPV cell for varying lamp voltages.

The actual I/V curve for the cell shows the small overall performance. The current is indeed very low but demonstrates the feasibility of the integration of hybrid and/or organic cells with this basic structure.

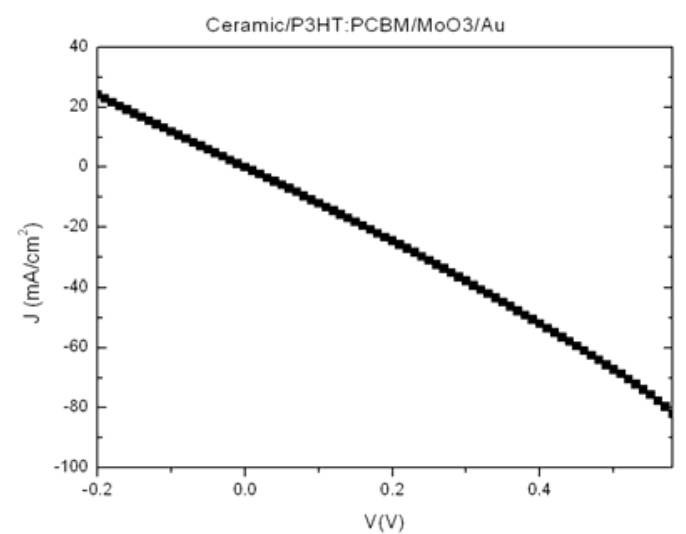

Figure 6. I/V curve for the BIHPV cell. 


\section{Conclusions}

The work presented shows a valid integration process for low cost BIPV cell production. The morphology attained avoids the common problems found when trying to build photovoltaic devices on top of ceramic materials. The feasibility of the process when joined to the low cost routine presented opens further research onto the best photovoltaic devices to build on top for the actual industrial feasibility of $\mathrm{BI}(\mathrm{H}) \mathrm{PV}$.

\section{References}

1. Green, M.A., Emery, K., Prog. In Photovolt : Res and App., 2, 1 (2007)

2. Iencinella, D., Centurioni, E., Busana, M.G., Solar Energy Mater. Solar cells, 93, (2009)

3. Orozco-Messana, J., Donderis,V., Cembrero, J., Hernández-Fenollosa, M.A., Qualicer 2008, (2008).

4. Daniel Lincot, Thin Solid Films, 487, 40-48 (2005).Lisha Zhang, Zhiganag Chen, Yiwen Tang, Zhijie Jia, Thin Solid Films, 492, 24-29, (2005).

5. J. Cembrero, A. Elmanouni, B. Hartiti, M. Mollar, B. Mari, Thin Solid Films, 198, 451-452 (2004).

6. Pawlowski, L., Johm Wiley \& Sons, The Science and Engineering of Thermal Spray Coatings (2008).

7. Menner, R., Gross, E., Ecicke, A., Dittrich, H., Springer, J., Dimmler, B., Rühle, U., Kaiser, M., Friedlmeier, T., Schock, H.W., Proceedings $13^{\text {th }}$ European Photovoltaic Solar Energy Conference, Nice, France (1995).

8. Culha, O., Celika, E., Ak Azema, N.F., Birlinka, I., Toparli, M., Turk, A., Journal of Materials Processing Technology, 204, issues 1-3 (2008).

9. L. Zhang, C. Zhigang, Y. Tang, Z. Jia, Thin Solid Films, 492, 24, (2005).

10. Reyes Tolosa, M.D., Orozco-Messana, J., Damonte, L.C., Hernandez-Fenollosa, M.A., Journal of The Electrochemical Society, 158 (8) 1-4 (2011).

11. B.C. Thompson, J.M. Fréchet, Angew. Chem. Int. Ed. 47 (2008) 58. 